\title{
Learning Management System Based on Assessment for Learning to Improve Computational Thinking
}

\author{
https://doi.org/10.3991/ijim.v16i04.28979 \\ Odhitya Desta Triswidrananta, Agung Nugroho Pramudhita ${ }^{(凶)}$, Indra Dharma Wijaya \\ Department of Information Technology, State Polytechnic of Malang, Malang, Indonesia \\ agung.pramudhita@polinema.ac.id
}

\begin{abstract}
There was a change in the implementation of education policies in the emergency period of the spread of the covid-19 virus, the learning process was carried out from home online using various learning resources. This condition triggers the emergence of behavioral problems and student competence in Indonesia. One of the distance learning media that was carried out during the pandemic was using the Learning Management System (LMS). Not only that, a policy evaluation needs to be carried out to evaluate the distance learning system that has been implemented in universities. This is because technology-based distance learning requires a different approach in terms of planning, implementation and evaluation. To increase the effectiveness of learning can use the assessment for learning (AfL) model. The learning process is also expected to be in accordance with learning that directs to have a computational thinking approach which is much needed considering that problem solving skills are needed in solving everyday problems. Based on the results of data analysis with 4D development model (define, design, develop, and disseminate), learning management system based on assessment for learning to improve computational thinking abilities got an average score of 85.2, which means it can be implemented well.
\end{abstract}

Keywords-learning management system, assessment for learning, computational thinking

\section{$1 \quad$ Introduction}

Since the end of 2019 the world has been hit by the Covid-19 pandemic and the State of Indonesia has also been affected by the pandemic, so that in the world of education a decision is needed to respond to this. Based on this [7], regarding the implementation of education policies in the emergency period of the spread of the corona virus disease, the impact of the Covid-19 virus, the learning process is carried out from home online in educational units using various learning resources through communication technology information, and media that support conceptually have a good purpose. This condition triggers the emergence of behavioral problems and student competence in Indonesia. One of the distance learning media carried out by the Malang State Polytechnic, especially in the Informatics Engineering study program during the covid-19 pandemic, used the Learning Management System (LMS) in its learning, but it was still 
not implemented optimally. Based on this, the researcher will develop a Learning Management System (LMS) as a distance learning media using open source applications. It is hoped that the results of this development can attract students' attention, provide motivation to students, and be adjusted to student interests. Learning Management System (LMS) is a system for managing training and education records, software for distributing programs over the internet with features for online collaboration. According to Ref. [1], Learning Management System is an application used to manage learning, deliver content, (Content Delivery System), and track online activities such as ensuring attendance in virtual classes, ensuring assignment collection time, and tracking student achievement. According to Ref. [8] in LMS Selection Best Practices, Learning Management System is an application that functions to automatically administer various learning activities. Thus, based on the opinions of these experts, it can be concluded that the Learning Management System is a software or software for administrative purposes, documentation, reports on an activity, teaching and learning activities, E-learning and online training materials. So it is hoped that the information conveyed through the media can be captured by students and tested in the teaching and learning process to see the practicality of using the Learning Management System.

Policy evaluation needs to be done to evaluate the distance learning system that has been implemented in universities. This is because technology-based distance learning requires a different approach in terms of planning, implementation and evaluation. In the implementation of distance learning, students need special attention, especially the infrastructure used, an adequate internet network and self-motivation to be able to participate in an independent learning process. To overcome these problems, an effective strategy is needed. One strategy that can be taken in improving the quality of graduates is through increasing the effectiveness of the practical learning process. According to Ref. [3] increasing the effectiveness of learning is to carry out an integrative and holistic assessment process with the learning process. Assessment is no longer seen solely as a process of measuring the achievement of students' abilities during and at the end of the program, but must be used as feedback to improve the learning process, both by students and by educators. Operationally, this integration is a process of finding and interpreting information or information related to the problems faced by students in their learning. Thus the assessment process is not only an assessment of learning but an assessment for learning.

Based on the results of researcher's observations in the 2019/2020 academic year at the Malang State Polytechnic, especially in the Informatics Engineering study program, from the results of student questionnaires, it was shown that $73 \%$ of distance learning was considered not effective and maximal. In addition, it was found that students' computational thinking in online learning is still lacking, especially in database courses, only $30 \%$ of students can solve problems, namely in terms of decomposition, pattern recognition, abstraction and algorithms. This is because the system applied to distance learning in the Informatics Engineering study program still requires special designs and techniques in terms of planning, implementation and evaluation so that they can be implemented properly. One that can increase the effectiveness of learning is the assessment for learning (AfL) model. Several studies have proven that the application of the assessment for learning (AfL) model is proven to increase the effectiveness of learning. One of the studies conducted by Ref. [9] proved that the application of AfL can increase 
the effectiveness of learning mathematics in junior high schools. In general, research on the application of AfL is still limited to the theoretical learning process which focuses more on the cognitive aspect. Thus, a research is needed that can produce an operational description of the application of the AfL model in practical learning. Assessment should be in the position of "assessment for learning" where assessment is not only to measure learning outcomes but can also be used to improve the quality of learning [5]. Related to this, Ref. [4] reveal that process assessment needs to be done because learning is not only about how many grades students get, but how students learn and improve their learning process to get results that match the criteria, so the appropriate assessment is assessment based on assessment for learning. So that the lecturer will provide feedback on the work or work of students to promote learning and improve or revise the work of students to be better [11].

Computational thinking is a thought process involved in formulating problems and expressing solutions in such a way that computers (humans or machines) can work effectively [14]. As stated in [2] explain that computational thinking is a cognitive process or thinking that involves logical reasoning in which problems are solved and artifacts, procedures and systems are better understood. Computational thinking approach is needed considering problem solving skills are needed in solving everyday problems. Computational thinking does not have to involve computers, but humans themselves must also have the ability to think computationally. According to Ref. [12], CT has been categorized into six main aspects. Then it was developed in computational thinking referring to these main aspects, becoming the dimensions of computational thinking consisting of 4 (four) parts, including: (1) decomposition; (2) pattern recognition; (3) abstraction; (4) algorithms.

Based on the description above, it appears that computational thinking is one of the most important things in learning. The use of a learning management system based on assessment for learning to improve computational thinking abilities is expected to make the learning process more meaningful. Therefore, the researcher conducted a research on learning management system based on assessment for learning to improve computational thinking ability in database learning.

\section{Method}

This learning management system based on assessment for learning to improve computational thinking abilities is included in the type of development research. The learning system that will be developed is in the form of a Learning Management System (LMS). This study uses a research development design with a 4D development model. According to [13], this 4D model consists of 4 main stages, namely; Define (limitation), Design (design), Develop (development), and Disseminate (deployment). The disseminate stage was not carried out due to limited research time, so that it can be said that in this research it has reached the Develop stage. This research was conducted at the State Polytechnic of Malang. The trial subjects were 25 students of the Informatics Engineering study program at the State Polytechnic of Malang.

At the Define stage, it consists of four steps, namely (a) Front-end analysis, (b) Learner Analysis; (c) Task Analysis; and (d) Concept Analysis. At this stage, a series 
of analyzes are carried out to define and define the basic problems and information that will underlie the design of the product to be developed. Research preparations such as preliminary observations and literature studies are carried out at this stage.

At the Design stage, the Constructing Criterion-Referenced Test is carried out, Media Selection, Format Selection and Initial Design. At this stage, the researcher conducts an initial design of the learning system that will be developed by using a Learning Management System based on Assessment for Learning. The database subject questions are based on Assessment for Learning and have question criteria that contain 4 elements of Computational Thinking, namely: (1) decomposition; (2) pattern recognition; (3) abstraction; (4) algorithms are entered into the LMS as content.

At the Develop stage, Expert Appraisal and Developmental Testing are carried out. Expert Appraisal is a way to get suggestions for improvement of the Learning Management System design. Experts consisting of two Malang State Polytechnic Lecturers who are material experts and learning media experts will become validators to assess and provide responses for the LMS design that has been made. From here it can be seen whether the Learning Management System that has been compiled is feasible to be continued at the next stage, namely Developmental Testing, whether it still needs to be revised. Data collection was carried out using a data collection instrument in the form of a checklist with a rating scale of 1 to 5 and a suggestion sheet. The data that has been obtained is then processed using the following formula:

$$
P=\frac{\sum_{1}^{2} x_{i}}{\sum_{1}^{2} x_{j}} \times 100 \%
$$

Description:

$P:$ preferred presentation

$\sum_{1}^{2} x_{i}:$ total score of assessment

$\sum_{1}^{2} x_{j}:$ maximum total score

(adapted from [10])

To find out whether the Learning Management System that has been compiled is valid or not, it needs to be revised or not, then the guidelines for assessing the validity of the learning program design are used as shown in the Table 1.

Table 1. Guidelines for assessing the validity of student learning program designs [6]

\begin{tabular}{|c|l|l|}
\hline Percentage (\%) & \multicolumn{1}{|c|}{ Validity Criteria } & \multicolumn{1}{c|}{ Description } \\
\hline $80-100$ & Very Valid & No Revision \\
\hline $66-79$ & Valid & No Revision \\
\hline $55-65$ & Quite Valid & No Revision \\
\hline $40-55$ & Less Valid & Revision \\
\hline $30-39$ & Invalid & Revision \\
\hline
\end{tabular}


If the expert test results at least meet the criteria are quite valid, then the Learning Management System design that has been made can be tested on students. Furthermore, at the Developmental Testing stage, the Learning Management System design that has met the minimum criteria for validity and has been improved according to suggestions and comments from experts, is tested on students of the State Polytechnic of Malang, especially in the Informatics Engineering study program. This Learning Management System trial aims to determine the level of student understanding of the material presented in it. The subjects of this Learning Management System trial consisted of 25 students. The data obtained were then processed using guidelines for assessing the validity of the student study program design as shown in Table 2.

Table 2. Guidelines for assessment of student learning management system validity [6]

\begin{tabular}{|c|l|}
\hline Student Score & \multicolumn{1}{|c|}{ Description } \\
\hline $80-100$ & Very good \\
\hline $66-79$ & Good \\
\hline $55-65$ & Enough \\
\hline $40-55$ & Not enough \\
\hline $30-39$ & Fail \\
\hline &
\end{tabular}

\section{Result}

You may mention here granted financial support or acknowledge the help you got from others during your research work. Simply delete this section if it doesn't apply.

The Learning Management System design that has been validated by a team of experts is a learning system in the form of an assessment for learning-based Learning Management System for database courses that contains 4 elements of computational thinking, namely: (1) decomposition; (2) pattern recognition; (3) abstraction; (4) algorithms. The results of the validation are used to assess the validity of the device prior to the implementation of the field trials, while the results of the field trials are used to assess the practicality and effectiveness of the Learning Management System that has been developed. The results of the validation are made a decision, whether the device still needs revision before testing or is ready to be tested in the field. The validators in this study consisted of two lecturers at the State Polytechnic of Malang.

The Table 3 below is the result of the validation of the Learning Management System. 
Table 3. Learning Management System Assessment Data

\begin{tabular}{|c|c|c|c|c|c|c|}
\hline \multirow{2}{*}{ No } & \multirow{2}{*}{ Pernyataan } & \multicolumn{2}{|c|}{ Validator } & \multirow{2}{*}{$\sum_{i=1}^{3} x_{i}$} & \multirow{2}{*}{$\sum_{i=1}^{3} x_{j}$} & \multirow{2}{*}{$\begin{array}{c}P \\
(\%)\end{array}$} \\
\hline & & $x_{1}$ & $x_{2}$ & & & \\
\hline 1 & $\begin{array}{l}\text { The presentation of material in this LMS enables } \\
\text { students to be able to decompose data, problems and } \\
\text { processes into smaller and simpler pieces or it can also } \\
\text { be a part which can be easier to manage, it can also be } \\
\text { referred to as categorization. }\end{array}$ & 3 & 3 & 6 & 8 & 75 \\
\hline 2 & $\begin{array}{l}\text { The presentation of material in this LMS enables } \\
\text { students to find and identify similarities or differences } \\
\text { in behavior, patterns or shapes in data. This can be } \\
\text { used and used to make predictions. }\end{array}$ & 3 & 3 & 6 & 8 & 75 \\
\hline 3 & $\begin{array}{l}\text { Presentation of material on this LMS will make } \\
\text { students able to announce (generalization), this } \\
\text { process usually uses an inductive method. It can be } \\
\text { used to identify and elicit a behavior. }\end{array}$ & 3 & 4 & 7 & 8 & 88 \\
\hline 4 & $\begin{array}{l}\text { The presentation of material on this LMS will enable } \\
\text { students to obtain information in solving the same } \\
\text { problem slowly, gradually, one by one, structured. }\end{array}$ & 3 & 2 & 5 & 8 & 62 \\
\hline \multicolumn{4}{|c|}{ Total } & 24 & 32 & 75 \\
\hline
\end{tabular}

Description:

$x_{1}$ : Validator 1

$x_{2}$ : Validator 2

$\sum_{i=1}^{2} x_{i}:$ Total scoring score

$\sum_{i=1}^{2} x_{j}:$ Maximum number of scoring scores

$\mathrm{P}$ : Rating percentage

Based on Table 3, regarding the results of the validation of the Learning Management System (LMS), the percentage of assessment is $75 \%$, so according to the Assessment Qualification Levels. Where the validation results have shown that the LMS based on assessment for learning for database courses has 4 elements of computational thinking, namely: (1) decomposition; (2) pattern recognition; (3) abstraction; (4) algorithms are included in the valid category. It can be concluded that the Learning Management System (LMS) that has been prepared is valid, so it does not need to be revised.

The Learning Management System (LMS) expert test shows valid results and has been corrected according to expert suggestions and comments. At this stage it was tested on 25 students. The LMS trial aims to determine the level of students' understanding of the material presented in the LMS. In Table 4, the following is the presentation of the LMS assessment data. 
Table 4. Learning Management System (LMS) Assessment and Student Understanding

\begin{tabular}{|l|l|c|c|c|l|}
\hline \multirow{2}{*}{ No } & \multirow{2}{*}{ Name } & \multicolumn{3}{|c|}{ Score } & \multirow{2}{*}{ Completeness Criteria } \\
\cline { 3 - 5 } & & $\mathbf{A}$ & $\mathbf{J 1}$ & $\mathbf{J} 2$ & \\
\hline 1 & ACH & 79 & 80 & 82 & Complete \\
\hline 2 & AKP & 81 & 81 & 78 & Complete \\
\hline 3 & ALP & 92 & 90 & 83 & Complete \\
\hline 4 & ASSA & 95 & 100 & 96 & Complete \\
\hline 5 & AYL & 77 & 76 & 83 & Complete \\
\hline 6 & BCK & 94 & 98 & 92 & Complete \\
\hline 7 & BFH & 86 & 89 & 87 & Complete \\
\hline 8 & BJOK & 78 & 68 & 74 & Not Complete \\
\hline 9 & DAM & 95 & 92 & 80 & Complete \\
\hline 10 & DPTG & 79 & 73 & 60 & Not Complete \\
\hline 11 & EGC & 86 & 78 & 78 & Complete \\
\hline 12 & EJK & 81 & 80 & 78 & Complete \\
\hline 13 & FHKI & 94 & 82 & 85 & Complete \\
\hline 14 & KRA & 77 & 73 & 74 & Not Complete \\
\hline 15 & LAD & 78 & 78 & 80 & Complete \\
\hline 16 & LIA & 81 & 80 & 92 & Complete \\
\hline 17 & MUA & 92 & 91 & 88 & Complete \\
\hline 18 & MKI & 94 & 87 & 80 & Complete \\
\hline 19 & NJK & 91 & 85 & 83 & Complete \\
\hline 20 & NKO & 77 & 82 & 80 & Complete \\
\hline 21 & PGIA & 94 & 74 & 73 & Not Complete \\
\hline 22 & PJIA & 86 & 80 & 82 & Complete \\
\hline 23 & SIA & 78 & 70 & 78 & Not Complete \\
\hline 24 & YGH & 86 & 83 & 81 & Complete \\
\hline 25 & ZIA & 79 & 80 & 78 & Complete \\
\hline JUMLAH & 2.130 & 2.050 & 2.025 & \\
\hline RATA-RATA & 85,2 & 82 & 81 & \\
\hline & & & & & \\
\hline & & & & & \\
\hline
\end{tabular}

Description:

A : Student Activities

J1 : Jobsheet 1

J2 : Jobsheet 2

In the aspect of student activity, the tryout got an average score of 85.2. Based on the rating scale for the level of student understanding, it was concluded that the test on students was included in the very good category in achieving indicators of activity aspects in the Learning Management System. In jobsheet 1 exercise, students got an average score of 82 . Based on the rating scale for the level of student understanding, it 
was concluded that the test on students was in the very good category. In the jobsheet 2 exercise, the test on students got an average score of 81 . Based on the rating scale for the level of student understanding, it was concluded that the test on students was also in the very good category. Thus, the Learning Management System (LMS), jobsheets 1 and 2 can be applied to research subjects.

The design of the learning system in the form of a LMS has passed the expert test stage and obtained valid results. The Learning Management System was then improved based on suggestions and comments from experts. In the next stage, the Learning Management System (LMS) was tested on 25 students. In the LMS there are aspects of student activity, jobsheet 1 , and jobsheet 2 . Analysis of the trial data shows that the test on students has achieved very good indicators in the aspect of student activity. Meanwhile, on jobsheets 1 and 2, good indicators have been achieved. After going through the assessment process, the final result is the development of a Learning Management System (LMS) learning system based on computational thinking.

\section{Conclusion}

Based on the results of data analysis, the Learning Management System (LMS) based on assessment for learning to improve computational thinking skills can be well implemented. Looking at the results of the validity trials by the validators, it shows that an LMS based on Assessment for Learning has 4 elements of Computational Thinking, namely: (1) decomposition; (2) pattern recognition; (3) abstraction; (4) algorithms get results with valid categories so there is no need for revision. This is also shown from the results of the LMS trial to 25 students with an average score of 85.2 which is in the very good category. In addition, this result is also strengthened by the test of jobsheets 1 and 2, which each get an average score of 82 and 81, which are also in the very good category. Thus, it can be concluded that the learning system in the form of LMS, based on assessment for learning to improve computational thinking abilities can be used in the learning process.

\section{$5 \quad$ References}

[1] Courts, B., \& Tucker, J. (2012). Using Technology To Create A Dynamic Classroom Experience. Journal of College Teaching \& Learning (TLC). Vol. 9, No. 2, 121-128. https://doi. org/10.19030/tlc.v9i2.6907

[2] Csizmadia, A., Curzon, P., Dorling, M., Humphreys, S., Ng, T., Selby, C., \& Woollard, J. (2015). Computational Thinking-A Guide for Teachers.

[3] Djemari Mardapi. (2008). Teknik Penyusunan Instrumen Tes Dan Non Tes. Yogyakarta: Mitra Cendikia Press.

[4] Elok. M., Kristantia dan Ramli Murni. (2017). Penerimaan dan Pengetahuan Mahasiswa tentang Assessment for Learning. Vol. 11, No. 1. Hal 55-60.

[5] Gibbs, G., \& Simpson, C. (2004). Condition under which Assessment Supports Students' Learning. Learning and Teaching in Higher Education, No. 1. 
[6] Irianti, N. P., \& Wijaya, E. M. S. (2019). Program Belajar Siswa Berbasis Prinsip Progressive Differentiation dan Intergrative Reconciliation. JIPM (Jurnal Ilmiah Pendidikan Matematika). Vol. 7, No. 2, 74-84. http://doi.org/10.25273/jipm.v7i2.3280

[7] Kemdikbud. (2020). Surat Edaran Mendikbud No 4 Tahun 2020 Tentang Pelaksanaan Kebijakan Pendidikan Dalam Masa Darurat Penyebaran Corona Virus Disease(COVID-19) Pusdiklat Pegawai Kementerian Pendidikan dan Kebudayaan. https://doi.org/10.33474/yur. v4i2.11239

[8] Kerschenbaum, Steven. (2009). LMS Selection Best Practices (White paper).

[9] Mansyur. (2009). Pengembangan Model Assessment for Learning pada Pembelajaran di SMP. Disertasi-Pascasarjana UNY.

[10] Rosidah, Kholifatur. (2006). Pengembangan bahan Ajar Matematika Materi Pokok Peluang untuk SMP Kelas I yang Mengacu Kurikulum 2004. Malang: FMIPA UM.

[11] Sabtiawan, Wahyu Budi, Sudibyo, Elok, Nurlita, Tutut. (2018). A Preliminary Design: "Assessment as Learning" to Accelerate Students' Achievements. Vol. 1, Hal 196-200. https://doi.org/10.2991/icst-18.2018.42

[12] Shute, J. V., Sun, C., \& Clarke, J. A. (2017). Demystifying Computational Thinking. Educational Research Review. USA. https://doi.org/10.1016/j.edurev.2017.09.003

[13] Trianto. (2009). Mendesain Model Pembelajaran Inovatif-Progresif; Konsep, Landasan dan Implementasinya. Jakarta: Kencana Prenada Group.

[14] Wing, J. M. (2017). Computational Thinking's Influence on Research and Education for All. Italian Journal of Educational Technology. Vol. 25, No. 2, 7-14.

\section{Authors}

Odhitya Desta Triswidrananta is a lecturer in the Department of Information Technology, at the State Polytechnic of Malang which is a university in Malang City, East Java, Indonesia (email: odhitya.desta@polinema.ac.id).

Agung Nugroho Pramudhita is a lecturer in the Department of Information Technology, at the State Polytechnic of Malang which is a university in Malang City, East Java, Indonesia (email: agung.pramudhita@polinema.ac.id).

Indra Dharma Wijaya is a lecturer in the Department of Information Technology, at the State Polytechnic of Malang which is a university in Malang City, East Java, Indonesia (email: indra.dharma@polinema.ac.id).

Article submitted 2021-12-28. Resubmitted 2022-01-27. Final acceptance 2022-01-28. Final version published as submitted by the authors. 